\title{
Factors affecting sunscreen utilization among students at Ganesha University Bali, 2017
}

\author{
A Santosa ${ }^{1 *}$ and A P Kusuma Wardhana ${ }^{1}$ \\ ${ }^{1}$ Faculty of Medicine and Health Sciences, Universitas Warmadewa, Denpasar, Bali \\ * omangbabe@gmail.com
}

\begin{abstract}
Continuous radiation from Ultra Violet A and Ultra Violet B can cause degeneration of connective tissues in the skin such as sun-aging (photo aging), skin cancer (photo carcinogenesis), and immunosuppression on transplantation. Based on data from the Meteorology, Climatology and Geophysics Center, Buleleng Regency is one of the districts in Bali that has a high level of sun exposure intensity as compared with other regions. The purpose of this study was to determine the factors that influence the use of sunscreen by students of the Ganesha University of Education. This study uses an analytical observational method with a cross-sectional design, using an interview based on a prepared and standardized questionnaire. The technique used for sample selection was systematic random sampling in 5th-semester students from seven faculties with 96 samples. The data analyzed using the chi- square test including assessing the p-value. The results showed a significant association between knowledge level and sunscreen usage $(\mathrm{p}=0.003)$, and lifestyle $(\mathrm{p}=0.033)$. It expected that people would be able to increase their usage of sunscreen in their areas through education regarding the function and danger of sunlight as well as maintaining a healthy lifestyle
\end{abstract}

Keyword : Affecting, Students, University Bali.

\section{Introduction}

Ultraviolet (UV) radiation has a variety of radiation waves, including UVA, UVB, UVC, infrared, and visible light with their respective effects on the skin. UVA radiation can penetrate window glass and can react with chemicals from topical drugs and drinking drugs so that it can cause a reaction called photoallergy and phototoxic reactions [1]. UVB radiation absorbed by window glass, but it is most dangerous in the summer and can penetrate the skin layer, causing the skin to burn, red, and the onset of inflammatory reactions, pigment discoloration, and non-melanoma skin cancers. Continuous exposure to UVA and UVB radiation can cause degeneration of connective tissue in the skin such as photo aging, skin cancer (carcinogenesis), and immunosuppression from transplantation [2].

The process of skin aging takes place slowly. The exact time limit between cessation of physical growth and the onset of the aging process is unclear, but most around the age of the second decade begins to show signs of skin aging. This condition influenced by the development of the hormone Dehydroepiandrosterone (DHEA) which reaches a peak around the age of 15-20 years and continues to decline along with the growth of age [3,4]. Based on data from the Meteorology, Climatology and Geophysics Agency, Buleleng Regency is one of the districts in Bali that has a high level of sun exposure intensity compared to other regions [5]. From the author's observation, most residents in Buleleng district are often exposed to sunlight because they rarely use long-sleeved clothing or trousers for reasons of being hot so the level of ultraviolet (UV) radiation on the skin is very high [6]. 
Therefore, the authors are interested in finding a relationship between the levels of knowledge of the effect of sun exposure on sunscreen utilization in students at the University of Education Ganesha. This research title is based on the high intensity of sunlight in the Buleleng area and the high risk factors of disorders of sun-related skin diseases during puberty. The author also expects the results of this research to be used as a reference for other studies.

\section{Method}

\subsection{Data Collection}

This research conducted in October and November 2017 at the Education University of Ganesha (UNDIKSHA) Singaraja. The type of research used is observational analytic with a cross-sectional method. The sample in this study was taken using systematic random sampling in 5th-semester students from seven faculties at the University of Education Ganesha.

The independent variable in this study is the level of knowledge and lifestyle of the students at the University of Education Ganesha, while the dependent variable is the level of sunscreen usage. Data collection techniques are carried out by filling out questionnaires through systematic direct interviews

\subsection{Statistical Analysis}

Hypothesis testing uses bivariate analysis with the chi-square test. The meaning limit is if $\mathrm{p}<0.05$, which means there is a meaningful relationship between the variables tested.

\subsection{Ethical Consideration}

The study reviewed and approved by the Research Ethics Committee of Universitas Udayana, Denpasar. Enrolment of the study participants is conditional on appropriate consent.

\section{Results And Discussion}

Table 1. Characteristic of the respondent $(n=96)$

\begin{tabular}{lccc}
\hline & Characteristic & Frequency & Percentage \% \\
\hline Gender & & \\
Male & 27 & 28.1 \\
$\quad$ Female & 69 & 71.9 \\
Age & & \\
19 years & 27 & 28.1 \\
20 years & 53 & 55.2 \\
21 years & 16 & 16.7 \\
\hline
\end{tabular}

Of the 96 sample people who participated in this study, 69 people $(71.9 \%)$ were female and, 27 were $(28.1 \%)$ male. Male respondent found to use sunscreen as high as $15(15.6 \%)$. Age 19 years 27 people (28.1\%), age 20 years 53 people (55.2\%), and age 21 years 16 people $(16.7 \%)$. 
Table 2. Respondents distribution based on study variables

\begin{tabular}{lcc}
\hline \multicolumn{1}{c}{ Variables } & Frequency & Percentage (\%) \\
\hline Knowledge level & & \\
Excellent & 52 & 54.2 \\
Good & 26 & 27.1 \\
Lifestyle & & \\
$\quad$ Appropriate & 89 & 92.7 \\
$\quad$ Inappropriate & 7 & 7.3 \\
Sunscreen Utilization & & \\
$\quad$ Rare & 36 & 37.5 \\
Frequent & 60 & 62.5 \\
\hline
\end{tabular}

The study found poor knowledge of sunscreen as high as $18(18.8 \%)$ among the students. Inappropriate lifestyle found in a minority $7(7.3 \%)$ of the students. We did not found a student who did not use the sunscreen even they are male.

Table 3. Distribution of sunscreen utilization concerning to study variables

\begin{tabular}{lccc}
\hline & \multicolumn{2}{c}{ Sunscreen Utilization } & Significance (p-value) \\
\cline { 2 - 3 } & Frequent & Rare & \\
\hline Level of knowledge & 38 & 14 & \\
Excellent & 17 & 9 & 0.003 \\
Good & 5 & 13 & \\
$\quad$ Poor & 51 & 31 & \multirow{2}{*}{0.033} \\
Life style & 2 & 5 & \\
$\quad$ Appropriate & & & \\
Inappropriate & & & \\
\hline
\end{tabular}

Ultraviolet radiation exposure is one of the predisposing factors to get melanoma, or other skin cancer in women [7]. This study consisted of sunscreen use survey and its possible correlation to some aspect of students at Universitas Ganesha Bali. In the current study, there may not have been enough variability or a large enough sample of specific subgroups to identify too many associations since this is a preliminary study

In this study, level of knowledge, $52(54.2 \%)$ samples had a right level of knowledge, and $38(73.1 \%)$ samples often used sunscreen. This finding is in line with the study of Heckman and Coups, which explains that a high level of knowledge about the benefits of sunscreen use or the importance of protecting their skin is directly proportional to the frequency of using sunscreens. Heckman and Coups study showed that of the 242 samples of sunscreen users studied, $134(55.4 \%)$ samples had a high level of knowledge about the benefits of sunscreen [6]. In line with the research of Koh et al. (2009), 55\% of the total sample had a secondary and high level of education tending to use sunscreen compared to groups with lower levels of education [8]. Armstrong at al. also got the same results, namely the higher the level of knowledge about the benefits of sunscreen and the dangers of sunlight, the higher the level of sunscreen use [9].

Lifestyle, 89 (92.7\%) samples had a good lifestyle with 53 (59.6\%) samples often-using sunscreen. Santmyire et al. showed the same results; $55 \%$ of the total sample did not have bad habits such as smoking, consuming alcohol [10]. Of the 55\% of the sample, 34 people always use sunscreen during their daytime activities, 27 people use protective clothing, and 31 people take refuge in shaded areas. This study is also in line with research conducted by Koh, Sharon, 
and Alan., Of 530 people who liked sunbathing 248 people (47\%) used sunscreen regularly, $46 \%$ men and $54 \%$ women from 248 people used sunscreen frequently [9]. Hall et al. (2012) who found a high level of good lifestyle in daily life influences the increased use of sunscreen [13] also obtained the same results.

\section{Conclusions}

Overall, the study findings do not inform results that contribute to the scientific aspect of the sunscreen use. Further study needs to study in-depth about the beneficial effect of the sunscreen in preventing skin disease among people who lived in tropical countries such as Indonesia. The high utilization of the sunscreen of the students implies the high level of their knowledge about the benefit of sunscreen in preventing medical problems related to sun exposure to the skin. However, this study provides more information particularly for researches in tropical countries. These data recommend that effort that is more considerable needed to increase sunscreen use among adolescent.

\section{References}

[1] Dupont E, Gomez J and Bilodeau D 2013 Beyond UV radiation: A skin under challenge Int. J. Cosmet Sci. 35(3) pp 224-32

[2] Poljšak B and Dahmane R 2012 Free radicals and extrinsic skin aging Dermatol. Res. Pract.

[3] Haryanti S 2013 Perbedaan self-esteem proses penuaan pada lansia pria dan wanita terhadap citra tubuh di UPT pelayanan sosial lanjut usia dan anak balita Binjai

[4] Makrantonaki E and Zouboulis C C 2010 The skin as a mirror of the aging process in the human organism-state of the art and results of the aging research in the German National Genome Research Network 2 (NGFN-2) Exp. Gerontol. 42(9) pp 879-86

[5] Kusrini I, Rooslamiati I, Sariadji K and Lisdawati V 2013 Riset kesehatan dasar (Riskesdas) 2013 Lap. Nas. 2013 pp 1-384

[6] Heckman C J and Coups E J 2011 Correlates of sunscreen use among high school students: a cross-sectional survey BMC Public Health 11(1) p 679

[7] Kutting B and Drexler H 2007 Evaluation of skin-protective means against acute and chronic effects of ultraviolet radiation from sunlight Curr. Probl. Dermatol 200734 pp 87-97

[8] Koh H K, Bak S M, Geller A C, Mangione T W, Hingson R W and Levenson S M 2009 Sunbathing habits and sunscreen use among white adults: results of a national survey Am. J. Public Health 87(7) pp 1214-7.

[9] Armstrong A W, Idriss N Z and Kim R H 2011 Effects of video-based, online education on behavioral and knowledge outcomes in sunscreen use: a randomized controlled trial Patient Educ Couns. 83(2) pp 273-7

[10] Hirst N G, Gordon L G, Scuffham P A and Green AC 2010 Lifetime cost effectiveness of skin cancer prevention through promotion of daily sunscreen use Value Heal. 15(2) pp 261-8

[11] Santmyire B R, Feldman S R and Fleischer A B 2010 Lifestyle high-risk behaviors and demographics may predict the level of participation in sun-protection behaviors and skin cancer primary prevention in the United States Cancer 92(5) pp 1315-24

[12] Jessop D C, Simmon L V and Spark V 2009 Motivational and behavioural consequences of self-affirmation intervention: A study of sunscreen use among women Psychol. Heal. 24(5) pp $529-44$ 
[13] Hall H I, May D S, Lew R A, Koh H K and Nadel M 2011 Sun protector behaviors of the US white population Prev. Med. (Baltim) 26(4) pp 401-7 